\title{
PENGARUH MAZHAB DALAM REGULASI WAKAF DI INDONESIA
}

\author{
Fakhruddin \\ Fakultas Syariah UIN Maulana Malik Ibrahim Malang \\ Email: fakhruddinsyarif@gmail.com
}

\section{Abstract}

Wakaf is one institution in Islam that really pays attention to people's prosperity. As a country in which the majority is Muslim, Indonesia the biggest chance to rise its people's prosperity through wakaf institution. With this chance, the government issues some regulations to organize and manage this Islamic institution in the forms of The Law, The Government Regulation, The Compilation, The Ministry of Religion Regulation, The Regulation of Indonesia Wakaf Institution, and so forth. Some that has been issued are based on Syafii Mazhab which most Indonesian Muslim relies on-besides Hanafi, Maliki, and Hanbali. This article discusses mazhab's effect in wakaf regulation in Indonesia, exactly on The 2004 Law Number 41 concerning Wakaf and Islamic Laws Compilation. By employing quantitative and library research for data collection and using formula $P=f / N \times 100 \%$ as data analysis, it can be concluded that Hanafi Mazhab affects the aforementioned law as much 78\%, and the influence of Maliki-Syafii Mazhab and Hanbali Mazhab is respectively 100\% and $85 \%$. Meanwhile, the influence of Hanafi in Islamic Laws Compilation is 85\%, and $100 \%$ for Maliki, Syafii and Hanbali.

Wakaf merupakan salah satu institusi dalam Islam yang sangat memperhatikan kesejahteraan umatnya. Sebagai negara yang mayoritas penduduknya muslim, Indonesia mempunyai peluangyang sangat besar untuk meningkatkan kesejabteraan masyarakatnya dengan institusi wakaf. Dengan peluang yang sangat besar inilah, maka pemerintah Indonesia membuat beberapa regulasi untuk mengatur dan mengelola institusi Islam ini, baik berupa Undang-undang, Peraturan Pemerintah, Kompilasi, Peraturan Menteri Agama, Peraturan Badan Wakaf Indonesia, dan sebagainya. Beberapa regulasi yang telah dibentuk tersebut tentu tidak terlepas dari pengaruh masyarakat Indonesia yang muslim dengan bermazhab Syafi' sebagai mazhab mayoritas, di samping mazhab Hanafi, Maliki, dan Hanbali. Tulisan ini 
mengkaji tentang pengaruh mazhab terhadap regulasi wakaf di Indonesia khususnya Undang-undang Nomor 41 Tahun 2004 tentang Wakaf dan Kompilasi Hukum Islam. Dengan menggunakan pendekatan kuantitatif dan kajian pustaka untuk mengumpulkan data serta analisis datanya menggunakan rumus: $P=f / N \times 100 \%$, maka dapat diambil kesimpulan bahwa mazhab Hanafi mempengarubi Undangundang Nomor 41 Tahun 2004 tentang Wakafsebanyak 78\%, mazhab Maliki dan Syafii sebanyak 100\% dan mazhab Hanbali sebanyak 85\%. Sedangan pengaruh mazhab hanafi terhadap Kompilasi Hukum Islam sebanyak 85\%, dan mazhab Maliki, Syafí, dan Hanbali masing-masing sebanyak 100\%.

Keywords: wakaf, mazhab, regulation

\section{Pendahuluan}

Wakaf merupakan salah satu institusi Islam yang bertujuan meningkatkan taraf hidup umat Islam. Allah SWT menciptakan manusia heterogen dalam berbagai aspek, termasuk tingkat ekonominya, di antara mereka ada yang kaya dan miskin, bahkan ada yang sangat kaya di satu sisi dan sangat miskin di sisi lainnya. Oleh karena itu, perbedaan merupakan sunatullah yang dimaksudkan agar kehidupan berjalan dengan baik dan seimbang ${ }^{1}$. Dengan wakaf, di samping zakat, infaq, dan shadaqah, maka distribusi kekayaan bisa berjalan sehingga kekayaan atau harta tidak hanya berputar di kalangan tertentu saja ${ }^{2}$.

Pada dasarnya wakaf bukanlah fenomena baru tetapi merupakan fenomena yang telah ada semenjak manusia diciptakan, sebab sangat bertalian erat dengan relasi positif antara sesama manusia yang apabila dikelola dengan baik maka akan dapat dirasakan hasilnya, yaitu kesejahteraan umat sebagaimana dicontohkan dizaman kejayaan Islam pada masa Dinasti Abbasiyah yang mengembangkannya sedemikian mungkin sehingga menjadi sumber pendapatan negara ${ }^{3}$.Sejarah peradaban Islam mencatat bahwa wakaf pertama kali dilakukan oleh Rasulullah SAW ketika membangun masjid Quba di Madinah. Wakaf kedua adalah masjid Dar al-Hijrah di Madinah yang dibangun Rasulullah SAW. Namun, menurut versi yang berbeda, wakaf pertama adalah merupakan wakaf yang dilakukan Rasulullah SAW setelah mengambil alih kepemilikan tujuh buah kebun milik seorang Mukhairaiq (orang yahudi yang terbunuh ketika perang uhud dan berpihak kepada muslim). Peristiwa wakaf ini kemudian diikuti oleh Umar bin Khattab serta sahabat-sahabat yang lain seperti Abu Bakar, Usman, Ali dan lainnya. Pada periode Abbasiyah, harta wakaf

\footnotetext{
Q.S. al-Nahl; 71.

Q.S. al-Hasyr; 7.

3 Muhammad Sofyan, "Wakaf antara Peluang dan Tantangan (Studi Konstruktif Bentuk Wakaf)", Jurnal Asas, Vol.ke 5, No. 1, Tahun 2013. h. 1.
} 
dan hasil-hasilnya tidak ditampung di Baitul Mal, namun dikelola oleh seorang Qadhi yang selalu diawasi. Pada periode Abbasiyah tersebut kemudian dibentuk Baitul Maal khusus untuk pengelolaan wakaf4.

Dengan demikian, maka wakaf merupakan instrumen keuangan Islam yang bertujuan menciptakan kepedulian kelompok aghniya' (the have/surplus unit) kepada para fuqara' (the have not/defisit unit). Wakaf menjadi salah satu media solidaritas sosial dalam Islam dalam bentuk infaq di jalan Allah SWT'. Wakaf juga merupakan salah satu instrument untuk menciptakan keadilan dan kesejahteraan dalam bidang ekonomi. Ciri utama wakaf adalah ketika wakaf telah ditunaikan, maka terjadi perpindahan kepemilikan dari kepemilikan pribadi menuju kepemilikan masyarakat muslim yang diharapkan abadi dan memberikan manfaat yang berkelanjutan (jariyah). Melalui wakaf diharapkan terjadi proses distribusi manfaat bagi masyarakat secara luas, dari manfaat pribadi (private benefit) menuju manfaat masyarakat (social benefit) ${ }^{6}$. Namun, nampaknya mayoritas umat Islam Indonesia mempersepsikan bahwa wakaf keagamaan lebih penting daripada wakaf untuk tujuan pemberdayaan sosial. Sehingga mereka lebih banyak mempraktekkan wakafkeagamaan, seperti masjid, mushalla, tanah untuk pemakaman dan sebagainya. Sementara untuk tujuan pemberdayaan, seperti wakaf pendidikan, pemberdayaan ekonomi dan kesejahteraan masyarakat belum dipandang penting. Selain itu, para wakif biasanya hanya menyumbangkan tanah atau bangunan sekolah kepada nazhir, namun menutup mata terhadap biaya operasionalnya dan pengembangan ekonominya. Akibatnya, banyak yayasan pendidikan Islam, yang berbasis wakaf, gulung tikar atau telantar ${ }^{7}$.

Sebagai negara dengan penduduk mayoritas muslim, maka Indonesia mempunyai peluang yang sangat besar untuk mengumpulkan dan mengelola wakaf ini. Berdasarkan data Kementerian Agama Republik Indonesia, jumlah tanah wakaf di Indonesia mencapai 373.211 lokasi dengan luas $50.403,50 \mathrm{Ha}^{8}$ atau menurut M. Nuh sebanyak 5,5 miliar meter persegi yang sebagian besar dimanfaatkan untuk pembangunan masjid dan pesantren?. Pengelolaan Wakaf pada Badan Wakaf Indonesia (BWI) tahun 2011 adalah Rp. 2.973.393.876,-.

4 Asep Dadan Suganda, “Konsep Wakaf Tunai”, Jurnal Islamiconomic: Jurnal Ekonomi Islam, Vol. 5, No. 2, Tahun 2014, h. 3.

5 Badan Wakaf Indonesia, Manajemen Wakaf di Era Modern (Jakarta: Badan Wakaf Indonesia, 2013), h. 2 .

6 John L. Esposito,ed., Ensiklopedi Oxford Dunia Islam Modern (Bandung: Mizan, 2001), h. 146.

7 Hamda Sulfinadia, "Kontroversi Mazhab tentang Wakaf Uang danImplikasinya terhadap UndangUndang Nomor 41Tahun 2004 tentang Wakaf”, Jurnal Ijtihad,Vol. 32, No. 2, Tahun 2016, h. 1.

8 http://siwak.kemenag.go.id/index.php, 10 Desember 2019.

9 https://khazanah.republika.co.id/berita/pxrpj2383/bwi-data-wakaf-tanah-capai-55-miliar-meterpersegi, 15 Desember 2019. 
Aset wakaf sebanyak Rp. 1.000.000.000,- digunakan sebagai biaya operasional Rumah Sakit Ibu dan Anak ${ }^{10}$ dan harta wakaf uang yang diterima mayoritas masih berupa deposito. Sedangkan, pengelolaan wakaf Tabung Wakaf Dompet Dhuafa' tahun 2013 sebesar Rp. 93.185.810.239,- yang peruntukannya lebih cenderung ke arah produktif seperti rumah sewa, ruko, lapangan futsal, perkebunan, dan sebagainya ${ }^{11}$.

Dengan besarnya potensi wakaf di Indonesia, maka pemerintah bersama Dewan Perwakilan Rakyat telah membuat beberapa peraturan atau regulasi. Terdapat beberapa regulasi wakaf di Indonesia, baik dalam bentuk Undangundang, kompilasi, Peraturan Pemerintah, Peraturan dan Keputusan Menteri Agama, maupun Peraturan Badan Wakaf Indonesia (BWI). Pengelolaan wakaf dalam bentuk Undang-undang diatur dalam Undang-Undang Nomor 41 Tahun 2004 tentang Wakaf ${ }^{12}$. Undang-undang ini kemudian diperkuat dengan Peraturan Pemerintah Nomor 42 Tahun 2006 tentang Pelaksanaan Undang-Undang Nomor 41 Tahun 2004 tentang Wakaf. Di samping itu, regulasi zakat juga diatur dalam Kompilasi Hukum Islam (KHI) yang merupakan Instruksi Presiden (Inpres) Nomor 1 Tahun 1991. Peraturan wakaf juga diatur dalam Peraturan Menteri Agama (PMA) Nomor 4 Tahun 2009 tentang Administrasi Pendaftaran Wakaf Uang, Keputusan Menteri Agama tentang Penetapan Bank Syariah sebagai Lembaga Keuangan Syariah (LKS) Penerima Wakaf Uang, Keputusan Direktur Jenderal Bimbingan Masyarakat (Dirjen Bimas) Islam Nomor OJ.111420 Tahun 2009

10 Laporan Pengelolaan Wakaf Uang Badan Wakaf Indonesia Periode 31 Desember 2007 s.d. Desember 2011.

11 Sebagai perbandingan bahwa luas tanah wakaf di Malaysia sebanyak 20,735.61 hektar. Negeri Johor adalah negeri yang paling banyak memiliki tanah wakaf, kemudian diikuti oleh Perak dan Pahang, sedangkan di Bangladesh terdapat 150.593 wakaf estate. Semua aset wakaf tersebut berbentuk aset tetap dan tidak dapat dipindahkan. Berarti, terdapat peluang besar bagi para nazhir untuk mengembangkan properti tersebut secara komersial melalui penggalangan dana dengan menjual sertifikat wakaf uang. Lihat Nilna Fauza, "Rekonstruksi Pengelolaan Wakaf: Belajar Pengelolaan Wakaf dari Bangladesh dan Malaysia", Jurnal Universum, Vol. 01, No. 2, Tahun 2015, h. 167. Lihat juga Jauhar Faradis, M. Yazid Affandi, dan Slamet Khilmi, "Manajemen Fundraising Wakaf Produktif:Perbandingan Wakaf Selangor (PWS) Malaysia dan Badan Wakaf Indonesia”, Jurnal Asy-Syir'ah, Vol. ke 49, No. 2, Tahun 2015, h.501.

12 Ketika Menteri Agama mendapatkan usulan dari Sekretariat Negara untuk menyusun draft RUU Wakaf, maka segera mengirim surat kepada Menteri Kehakiman dan Hak Asasi manusia untuk segera melakukan pembaharuan perundang-undangan wakaf. Secara konsisten, dalam surat itu Menteri Agama menyebutkan latar belakang aspek ekonomi produktif dalam wakaf; bahwa pengelolaan wakaf di tanah air memiliki peluang dan prospek pengembangan yang positif, baik dari segi kuantitas maupun pemanfaatannya; perkembangan wakaf pada waktunya akan mengarah menjadi kegiatan investasi dan ekonomi produktif dalam rangka pengentasan kemiskinan dan memajukan kesejahteraan masyarakat, sebagaimana yang telah berjalan di beberapa negara muslim seperti Arab Saudi, Mesir, Tunisia, Turki, Bangladesh dan lain-lain. Lihat Hadi, Solikhul, "Pemberdayaan Ekonomi Melalui Wakaf”, Jurnal Zakat dan Wakaf,Vol. 4, No. 2, Tahun 2017, h. 231. 
tentang Model, Bentuk, dan Spesifikasi Formulir Wakaf Uang, Peraturan Badan Wakaf Indonesia (BWI) Nomor 4 Tahun 2010 tentang Pedoman Pengelolaan dan Pengembangan Harta Benda Wakaf,dan Peraturan Badan Wakaf Indonesia (BWI) Nomor 01 Tahun 2009 tentang Pedoman Pengelolaan dan Pengembangan Harta Benda Wakaf Bergerak berupa Uang.

Pembentukan beberapa regulasi wakaf di atas tentu tidak terlepas dari latar belakang masyarakat Indonesia yang muslim dengan bermazhab Syafi'i sebagai mazhab mayoritas, di samping mazhab Hanafi, Maliki, dan Hanbali. Oleh karena itu tentunya setiap regulasi yang dibentuk di Indonesia akan dipengaruhi oleh latar belakang mazhab yang mereka anut tersebut. Namun sejauh mana mazhab Syafi'i dan mazhab tiga lainnya mempengaruhi regulasi wakaf di Indonesia menjadi fokus tulisan ini.

Penelitian tentang wakaf telah menarik perhatian banyak orang, baik dalam bentuk disertasi, tesis, skripsi, ataupun dalam bentuk penelitian lepas. Sudirman meneliti dua lembaga atau institusi yaitu Lembaga Amil Zakat Dompet Dhuafádan Pondok Pesantren Tebuireng dengan perspektif Total Quality Management (TQM). Adapun kesimpulan dari penelitian ini yaitu bahwa dalam fokus kepada pelanggan. Wakaf sudah dikelola secara modern. Misalnya memberikan pelayanan terbaik untuk wakaf yang dianggap sebagai pelanggan.Layanan prima diberikan dalam rangka meningkatkan penerimaan aset wakaf seperti yang dilakukan oleh Dompet Dhuafa' dan PP Tebuireng. Ada dua jenis pelanggan, yaitu pelanggan internal maupun pelanggan eksternal. Berbagai macam fasilitas diberikan oleh Dompe Dhuafa' untuk pelanggan eksternalnya. Misalnya jemput wakaf, ucapan terima kasih, bulletin, brosur program hingga informasi di website. Adapun PP Tebuireng memberikan layanan kepada pelanggan eksternal berupa penjagaan dan pengelolaan asset secara baik hingga kunjungan rutin kepada wakif. Doa Bersama untuk wakif yang telah meninggal dunia. Sedangkan, untuk perbaikan proses Dompet Dhuafa' dan PP Tebuireng sama-sama melakukan sejumlah kegiatan dan terobosan yang berorientasi kepada perbaikan. Kemudian dalam hal keterlibatan total, Dompet Dhuafa' dan PP Tebuireng melibatkan seluruh elemen lembaga, mulai dari pimpinan, karyawan, hingga mitra kerja ${ }^{13}$.

Jaih Mubarok melakukan penelitian tentang wakaf produktif yang menyimpulkan bahwa; pertama, aspek-aspek yang terkandung dalam UU No. 41/2004 tentang Wakaf dan PP No. 42/2006 tentang Pelaksanaan UU No. 41/2004 tentang Wakaf adalah aspek regulasi dan aspek struktur hukum wakaf. Kedua, perluasan objek wakaf, jangka waktu yang dinamis merupakan strategi

13 Sudirman, TQM untuk Wakaf (Malang: UIN-Maliki Press, 2013), h. 247-249. 
yang dilakukan untuk mewujudkan wakaf produktif. Hal ini dilakukan dengan cara mengakomodasi pendapat Abu Hanifah mengenai gagasan wakaf tidak termasuk akad lazim. Selain itu, perlu lembaga baru sebagai regulator, fasilitator, koordinator, motivator, dan pengembang kualitas nazhir. Kesimpulan ketiga yaitu Badan Wakaf Indonesia merupakan lembaga baru yang dibentuk dalam rangka menjadikan wakaf sebagai media untuk memakmurkan masyarakat. Adapun Lembaga Keuangan Syariah Penerima Wakaf Uang (LKS-PWU) yang bertugas menerima dan mengelola wakaf uang serta surat berharga lainnya, dan menyalurkan hasilnya kepada pihak-pihak yang berhak menerimanya. LKS-PWU juga dapat berperan sebagai nazhir wakaf ${ }^{14}$.

M. Athoillah dalam disertasinya meneliti tentang hukum wakaf benda bergerak dan tidak bergerak dalam fikih dan peraturan perundang-undangan di Indonesia menyimpulkan beberapa hal, yaitu (1) periodisasi sejarah pertumbuhan dan perkembangan wakaf di Indonesia dapat dibagi kepada empat fase, yaitu; pertama, periode awal masuknya Islam ke Indonesia sampai masa kolonial Belanda dan Jepang. Kedua, periode tahun 1945-1977 didasarkan pada pemikiran bahwa pada periode ini regulasi wakaf hanya mengatur wakaf benda tidak bergerak berupa tanah milik. Ketiga, periode tahun 1977-1991 yang merupakan awal diberlakukannya PP Nomor 28/1977 tentang Perwakafan tanah milik yang pelaksanaannya diatur dengan PMA Nomor 1/1978. Keempat, periode 1991 sampai sekarang yang merupakan awal diberlakukannya KHI yang memuat buku tiga tentang wakaf. (2) dinamika regulasi wakaf hingga diundangkannya UU Nomor 41/2004 tentang Wakaf dan PP Nomor 42/2006 tentang Pelaksanaan Wakaf. Institusi wakaf berkembang seiring dengan penyebaran Islam. Seperti tradisi wakaf tanah untuk rumah ibadah, madrasah dan benda wakaf bergerak berupa al-Qur'an, kitab, dan sajadah. (3) pemikiran hukum wakaf benda bergerak dalam perundang-undangan di Indonesia ditandai dengan masuknya wakaf benda bergerak dalam Inpres Nomor 1/1991 tentang KHI dan UU Nomor 41/2004 tentang Wakaf ${ }^{15}$.

Dari beberapa penelitian di atas, tidak ada yang memfokuskan penelitiannya pada pengaruh mazhab fikih terhadap regulasi wakaf di Indonesia walaupun penelitian terhadap regulasi wakaf di Indonesia sudah dilakukan oleh beberapa peneliti. Oleh karena itu, maka penelitian ini penting untuk dilakukan untuk melengkapi penelitian yang sudah ada.

14 Jaih Mubarok, Wakaf Produktif (Bandung: Simbiosa Rekatama Media, 2008), h. 191.

15 M. Athoillah, Hukum Wakaf (Bandung: Yrama Widya, 2014), h. 237. 


\section{Metode Penelitian}

Penelitian ini menggunakan pendekatan kuantitatif. Dalam melakukan penelitian kuantitatif, seorang peneliti perlu menentukan variabel-variabel penelitian dan selanjutnya merumuskan hipotesa berdasarkan hubungan antara variabel penelitian ${ }^{16}$. Penelitian ini mengukur hubungan antara variabel bebas yaitu mazhab fikih yang empat dan variabel terikat yaitu regulasi wakaf. Pendekatan kuantitatif ini digunakan karena memungkinkan dilakukan pencatatan dan analisis data hasil penelitian secara eksak. Adapun Jenis datanyaterdiri atas bahan hukum primer dan skunder. Bahan hukum primer diperoleh dari sumber primer, yaitu UU Nomor 41/2004 tentang Wakaf, KHI, dan kitab empat mazhab fikih. Sedangkan bahan hukum skunder diperoleh dari sumber skunder, yaitu berupa dokumen-dokumen yang bisa mendukung dan melengkapi data primer, seperti buku, jurnal, laporan penelitian, dan lain-lain. Kemudian teknik yang digunakan untuk mengumpulkan data-data yang diteliti dengan menggunakan teknik kajian pustaka yaitu dengan mengumpulkan bahan hukum primer dan skunder untuk kemudian dibaca dan dianalisis.

Sedangkan teknik analisis datanya menggunakan analisis komparatif yakni membandingkan UU Nomor 41/2004 tentang Wakaf dan KHI. Di samping itu, dibandingkan juga komposisi mazhab fikih secara kuantitatif. Adapun rumus yang digunakan dalam menentukan prosentase adalah:

$$
\begin{aligned}
& \mathrm{P}=\mathrm{f} \times 100 \% \\
& \quad \mathrm{~N} \\
& \text { Keterangan: } \\
& \mathrm{P}=\text { Prosentase } \\
& \mathrm{f}=\text { Frekwensi pada klasifikasi } \\
& \mathrm{N}=\text { Jumlah frekwensi dari seluruh klasifikasi }
\end{aligned}
$$

\section{Pembahasan}

\section{Mazhab dalam Islam}

Dalam pembahasan ini diuraikan secara urut pengaruh empat mazhab fikih terhadap regulasi wakaf di Indonesia, yaitu UU Nomor 41/ 2004 tentang Wakaf dan KHI. Namun sebelumnya dibahas terlebih dahulu tentang konsep mazhab dalam Islam dan regulasi wakaf di Indonesia.

16 Iskandar, Metodologi Penelitian Pendidikan dan Sosial, Kuantitatif dan Kualitatif, (Jakarta: Gaung Persada Press, 2008), h. 48. 
Secara bahasa, mazhab dapat berarti pendapat (view, opinion, ray), kepercayaan, ideologi (belief, ideology, al-mu'taqad), doktrin, ajaran, paham, aliran (doctrine, teaching, school, al-ta'lim wa al-thariqah) ${ }^{17}$. Pada awal sejarah perkembangan hukum Islam, syariat dirumuskan dalam bentuk prinsip dasar yang universal pada masa Rasulullah SAW dan nash illah (alasan) yang bersifat parsial untuk diambil hukumnya kemudian diterapkan pada kasus baru di setiap masa. Di masa ini tidak ada peluang terjadi konflik dikalangan umat Islam. Selain karena al-Qur'an masih diturunkan, Rasulullah SAW menjadi rujukan utama dalam fatwa dan peradilan. Pasca wafatnya Rasulullah SAW, para sahabat dan tabiin melakukan ijtihad dalam rangkamengembangkan prinsip dasar yang universal. Prinsip ini kemudian diaplikasikan pada kasus parsial yang belum ditemukan hukumnya dalam al-Qur'an maupun sunah. Dakwah Islam telah menyebar ke luar jazirah Arabi, seperti ke Persia, Iraq, Mesir, dan Suriah.

Umat Islam memiliki perbedaan adat dalam muamalah dan berbagai aspek kehidupan lainnya. Umat Islam menemui berbagai kasus yang belum pernah ditemui sebelumnya. Tidak jarang kasus-kasus baru belum ada hukumnya secara eksplisit dalam nash. Hal ini menjadi tanggung jawab para khalifah dan sahabat besar (kibar al-shahabah) untuk berijtihad dengan menerapkan prinsip-prinsip dasar universal yang terdapat dalam al-Qur'an dan sunah mengenai masalahmasalah baru tersebut. Salah satu metode yang digunakan ulama adalah ijtihad bi al-ra'yi (hasil pemikiran manusia). Model ijtihad ini merupakan kecenderungan hati setelah melakukan pemikiran, perenungan, dan penelitian, serta pengkajian terhadap sisi kebenaran dari tanda-tanda yang kontradiktif. Cakupan ráyu pada masa itu tidak hanya terbatas pada qiyas semata, akan tetapi juga meliputi apa yang secara tekhnis fiqh dikenal beberapa istilah, seperti istihsan, istishab, sad aldzari'ah, al-maslahah al-mursalah, di samping perhatian terhadap urf.

Penggalian hukum di masa ini terbatas pada kasus yang terjadi (aktual). Mereka tidak memprediksi masalah yang bakal terjadi kemudian, lalu mencarikan hukumnya. Sumber hukum pada masa ini telah berkembang menjadi al-Qur'an, sunah, ijma' dan ra'yu. Dengan melakukan ijtihad, para sahabat telah menghasilkan pendapat hukum yang berbeda-beda. Menurut Abu Zahrah, perbedaan tersebut disebabkan oleh beberapa faktor, yaitu: Perbedaan pemahaman mereka terhadap al-Qur'an; Perbedaan dari sisi sunah; Perbedaan dalam penggunaan ra'yu ${ }^{18}$.

17 A. Qodri Azizy, Reformasi Bermazhab, Sebuah Ikhtiar Menuju Ijtihad Sesuai Saintifik-Modern (Jakarta: Teraju, 2003), h. 16-17.

18 Abdul Aziz Dahlan et al., Ensiklopedi Hukum Islam (Jakarta: PT. Ichtiar Baru Van Hoeve, 1996), h. 226. 
Selanjutnya pada masa tabiin, sumber penggalian hukum sama dengan masa sahabat, yaitu al-Qur'an, sunah, ijma', dan ra'yu. Namun pada masa ini telah terjadi banyak peristiwa yang berpengaruh besar terhadap munculnya mazhab fiqh, yaitu: Perselisihan kaum muslimin sekitar masalah kekhalifahan; Menyebarnya para sahabat ke daerah-daerah sejak masa Utsman bin Affan; Tersebarnya periwayatan hadits; Munculnya para pendusta dalam periwayatan hadits; Terpecahnya ulama' di kalangan jumhur ke dalam ablal-ra'y dan ahl al-hadits, yaitu dua golongan yang kontras dari kalangan jumhur ulama' karena masing-masing mempunyai orientasi fiqh yang berlainan ${ }^{19}$.

Golongan abl al-ra'y dan abl al-hadits inilah yang menjadi cikal bakal lahirnya mazhab tekstual dan kontekstual. Kalau dilihat ke belakang (masa sahabat), sebenarnya abl al-ra'y dan abl al-hadits sudah muncul. Umar bin Khattab dan Abdullah bin Masud dapat dikategorikan kedalam ablal-ra'y, sedangkan Abdullah bin Umar dapat dimasukkan kedalam kelompok abl al-hadits.

Mazhab-mazhab yang muncul kemudian berafiliasi kepada salah satu aliran tersebut. Dalam mazhab sunni, khususnya mazhab yang empat (Hanafi, Maliki, Syaf'i i dan Hanbali) pun mengerucut kepada salah satu aliran tersebut. Walaupun sebagian ulama' mengatakan bahwa mazhab Syafi'i merupakan sintesa dari mazhab Hanafi yang abl al-ro'yi dan mazhab Maliki yang abl al-hadits.

\section{Regulasi Wakaf di Indonesia}

Di Indonesia, sejarah mengenai wakaf telah ada sejak dulu, pada masa kerajaan Aceh Darussalam yang berdiri pada 916 H/1511 M, praktek wakaf sudah dilakukan. Kerajaan ini mempunyai undang-undang dasar yang bernama Kanun Meukuta Alam (Kanun al-Asyi). Dalam undang-undang ini terdapat satu lembaga yang bernama Balai Mausara dan bertugas mengelola segala hal yang menyangkut wakaf. Meusara yang bermakna wakaf memegang peran penting dalam kerajaan ini.

Pada masa penjajahan Belanda, pelaksanaan wakaf masih sangat sederhana, tidak disertai administrasi, cukup dilakukan ikrar (pernyataan) secara lisan. Pengurusan dan pemeliharaan tanah wakaf kemudian diserahkan kepada nazhir. Namun, saat ini muncul berbagai problem perwakafan seperti hilangnya aset, sengketa dipengadilan, hingga aset berpindah tangan kepada pihak lain karena lemahnya administrasi wakaf. Bahkan pada periode 1500-1600, di kantor wilayah Departemen Agama Provinsi Jawa Timur atau selama abad VII tercatat hanya enam wakaf yaitu tanah seluas $20.615 \mathrm{~m} 2$, kemudian pada pertengahan kedua

19 Aziz Dahlan, Abdul, et al., Ensiklopedi......, h. 227-228. 
abad XVII terdapat 61 wakaf dengan luas $94.071 \mathrm{~m} 2$ yang terdiri atas wakaf tanah kering sebanyak 57 wakaf dan empat wakaf sawah. Seiring dengan perkembangan dan pemahaman agama yang makin hari makin paripurna, maka pada pertengahan pertama abad XIX tercatat sebanyak 79 wakaf yang terdiri dari 78 tanah kering dan satu wakaf sawah. Selanjutnya pada pertengahan kedua abad tersebut tercatat 224 wakaf yang terdiri atas wakaf tanah kering sebanyak 219 dan 5 wakaf sawah. Perkembangan menggembirakan terlihat pada 1905, Sekretaris Gubernur Hindia Belanda mengeluarkan surat edaran (Sirculair Van De Gonvernement Secretaris) pada 31 Januari 1905 No. 435 (Bijlabad 1905, No. 6196 tentang Toezicht Opden Bouw Van Mohammadeance Bedhuizen yang berisi perintah kepada para Bupati untuk membuat daftar rumah ibadat Islam yang dibangun di atas tanah wakaf. Tujuannya adalah memantau aset wakaf agar tidak bertentangan dengan kepentingan umum ${ }^{20}$.

Pada masa kemerdekaan, wakaf mulai mendapat perhatian lebih dari pemerintah melalui Departemen Agama. Walaupun sebenarnya Undang-undang perwakafan tanah lahir setelah lima belas tahun Indonesia merdeka, namun sebelum lahirnya undang-undang tentang perwakafan tanah, pemerintah melalui Departemen Agama melahirkan beberapa petunjuk tentang pelaksanaan wakaf, antara lain: Petunjuk tentang perwakafan tanah tanggal 22 Desember 1953; Petunjuk tentang wakaf yang bukan milik kemasjidan merupakan tugas bagian D (ibadah sosial), jawatan urusan agama berdasarkan surat edaran jawatan urusan agama tanggal 8 oktober 1956 No. 3/D/1956; Petunjuk tentang prosedur perwakafan tanah berdasarkan surat edaran jawatan urusan agama No. 5/1956 21.

Adapun pengelolaan wakaf di Indonesia secara umum terdiri atas 3 periode besar, yaitu periode tradisional, periode semi profesional, dan periode profesional. Dalam periode tradisional, wakaf masih ditempatkan sebagai ajaran yang murni dimasukkan dalam kategori ibadah mahdhah (pokok), yaitu di hampir semua benda-benda wakaf diperuntukkan bagi kepentingan pembangunan fisik, seperti masjid, mushalla, pesantren, kuburan, yayasan, dan sebagainya. Dengan demikian, maka keberadaan wakaf belum dapat memberikan kontribusi sosial yang lebih luas karena hanya untuk kepentingan yang bersifat konsumtif. Kondisi tersebut disebabkan oleh beberapa hal, di antaranya kebekuan paham terhadap wakaf, nazhir wakaf yang masih tradisional, dan peraturan perundangan yang belum memadai.

Dalam periode semi profesional, kondisinya relatif masih sama dengan periode tradisional, namun pada periode ini sudah mulai dikembangkan pola 20 Farid Wajdy dan Mursyid, Wakaf dan Kesejabteraan Umat (Yogyakarta: Pustaka Pelajar, 2007), h. 38. 21 Siska Lis Sulistiani, Pembaharuan Hukum Wakaf di Indonesia (Bandung: Refika Aditama, 2017), h. 20. 
pemberdayaan wakaf secara produktif meskipun belum maksimal. Selain itu juga sudah mulai dikembangkannya pemberdayaan tanah-tanah wakaf untuk bidangbidang pertanian, pendirian usaha-usaha kecil seperti toko-toko ritel, koperasi, penggilingan padi, usaha bengkel dan sebagainya yang hasilnya untuk kepentingan pengembangan di bidang pendidikan (Pondok Pesantren), meskipun pola pengelolaannya masih tradisional. Di samping itu, terdapat juga pola pemberdayaan wakaf dengan pengkajian dan penelitian secara intensif terhadap pengembangan wacana pemikiran Islam modern.

Kemudian pada periode profesional yaitu kondisi dimanadaya tarik wakaf sudah mulai dilirik untuk diberdayakan secara profesional-produktif. Keprofesionalan yang dilakukan meliputi aspek menejemen, SDM ke-nazhir-an, pola kemitraan usaha, bentuk benda wakaf yang tidak hanya berupa harta tidak bergerak, seperti uang, saham dan surat berharga lainnya, dukungan political will pemerintah secara penuh, seperti lahirnya Undang-Undang Nomor 41 Tahun 2004 tentang Wakaf ${ }^{22}$.

Undang-Undang Nomor 41 Tahun 2004 tentang Wakaf terdiri atas 11 bab dan 71 pasal. Pada umumnya, bab-bab tersebut dibagi ke dalam bagian-bagian yang lebih kecil. Setiap bab dibagi ke dalam pasal-pasal dan setiap pasal dibagi lagi ke dalam ayat-ayat. Akan tetapi pasal juga kadang dibagi ke dalam huruf a, b, c, dan seterusnya. Bab I adalah ketentuan umum yang hanya terdiri atas satu pasal. Pasal ini dibagi menjadi bab yang merupakan penjelasan dan atau definisi seluruh unsur yang terdapat dalam undang-undang. Bab II berisi dasar-dasar wakaf. Bab ini terdiri atas 30 ayat (ayat 2 sampai ayat 31 ) dan 10 bagian: (1) umum; keabsahan dan pembatalan wakaf (Pasal 2-3), (2) tujuan dan fungsi wakaf (Pasal 4-5), (3) unsur-unsur wakaf (Pasal 6), (4) Wakif (Pasal 7-8), (5) nazhir (Pasal 9-14), (6) harta benda wakaf (Pasal 15-16), (7) ikrar wakaf (Pasal 17-21), (8) peruntukan harta benda wakaf(Pasal 22-23), (9) wakaf dengan wasiat (Pasal 24-27), dan (10) wakaf benda bergerak berupa uang (Pasal 28-31).

Adapun bab III berisi tentang aturan pendaftaran dan pengumuman harta benda wakaf yang terdiri atas 8 pasal (Pasal 32-39) yang berisi tentang peraturan pendaftaran benda wakaf, PPAIW, penukaran dan pengubahan peruntukan benda wakaf, dan badan wakaf. Bab IV berisi tentang aturan perubahan status harta benda wakaf (Pasal 40-41) juga cegahan-cegahan yang menyangkut benda wakaf dan pengecualiannya. Bab V berisi tentang aturan pengelolaan dan pengembangan harta benda wakaf yang terdiri atas 5 pasal; (Pasal 42-46) dan berisi tentang kewajiban

22 Direktorat Pemberdayaan Wakaf, Strategi Pengembangan Wakaf Tunai di Indonesia (Jakarta: Departemen Aagama, 2007), h. 1-6. 
nazhir, lembaga penjamin, pengembangan benda wakaf, dan pemberhentian nazhir. Bab VI berisi tentang aturan Badan Wakaf Indonesia (BWI) yang terdiri atas 15 pasal (Pasal 47-61) dan 7 bagian. Bab ini berisi (1) kedudukan dan tugas BWI, (2) organisasi BWI, (3) anggota BWI, (4) pengangkatan dan pemberhentian anggota BWI, (5) pembiayaan BWI, dan (6) pertanggungjawaban BWI. Kemudian Bab VII berisi tentang aturan penyelesaian sengketa. Bab VIII berisi tentang pembinaan dan pengawasan. Bab IX berisi tentang aturan ketentuan pidana dan sanksi administratif. Bab X berisi tentang ketentuan peralihan dan Bab XI berisi tentang ketentuan penutup.

Regulasi wakaf kedua adalah Kompilasi Hukum Islam yang merupakan sekumpulan materi hukum Islam yang ditulis pasal demi pasal, berjumlah 229 pasal, terdiri atas tiga kelompok materi hukum, yaitu Hukum Perkawinan sebanyak 170 pasal, Hukum Kewarisan termasuk Wasiat dan Hibah sebanyak 44 pasal, dan Hukum Perwakafan sebanyak 14 pasal, ditambah satu pasal ketentuan penutup yang berlaku untuk ketiga kelompok hukum tersebut. KHI disusun melalui jalan yang sangat panjang dan melelahkan karena pengaruh perubahan sosial politik terjadi di Indonesia dari masa ke masa.

Term kompilasi diambil dari bahasa Inggris compilation atau dalam bahasa Belanda compilate yang diambil dari kata compilare yang artinya mengumpulkan bersama-sama, seperti mengumpulkan peraturan-peraturan yang tersebar berserakan di mana-mana. Istilah ini kemudian dipergunakan dalam bahasa Indonesia yaitu kompilasi sebagai terjemahan langsung dari kata tersebut. Menurut Abdurrahman sebagaimana dikutip oleh Ahmad Rofiq bahwa kompilasi adalah kegiatan pengumpulan dari berbagai bahan tertulis yang diambil dari berbagai buku/ tulisan mengenai sesuatu persoalan tertentu. Pengumpulan bahan dari berbagai sumber yang dibuat oleh beberapa penulis yang berbeda untuk ditulis dalam suatu buku tertentu sehingga dengan kegiatan ini semua bahan yang diperlukan dapat ditemukan dengan mudah. Dalam konteks hukum, kompilasi sedikit berbeda dengan kodifikasi yang berarti pembukuan (al-tadwin), yaitu sebuah buku hukum tertentu atau buku kumpulan yang memuat aturan atau bahan-bahan hukum tertentu, pendapat hukum, atau juga aturan hukum ${ }^{23}$. Selanjutnya disebutkan bahwa apabila dihubungkan dengan penggunaan term kompilasi dalam konteks hukum Islam di Indonesia, ia biasa difahami sebagai fikih dalam bahasa perundang-undangan yang terdiri dari bab-bab, pasal-pasal, dan ayat-ayat. Akan halnya Kompilasi Hukum Islam di Indonesia, tidak secara spesifik menjelaskan terminologi "kompilasi" tersebut. Oleh karena itu, pemahaman secara utuh dan komprehensif terhadap

23 Ahmad Rofiq, Hukum Islam di Indonesia (Yogyakarta: Gama Media, 2001), h. 76. 
istilah "kompilasi" kiranya baru diperoleh setelah mengetahui sejarah dan proses pembentukannya ${ }^{24}$.

Ide kompilasi hukum muncul sesudah beberapa tahun Mahkamah Agung membina bidang tekhnis yustisial Peradilan Agama. Tugas pembinaan dimaksud didasari oleh UU Nomor 14/1970 tentang Ketentuan Pokok Kekuasaan Kehakiman. Pasal 11 ayat (1) undang-undang tersebut menyatakan bahwa organisasi, administrasi, dan keuangan pengadilan dilakukan oleh departemen masing-masing, sedangkan pembinaan teknis yustisial dilakukan oleh Mahkamah Agung. Meskipun undangundang tersebut ditetapkan tahun 1970, tetapi pelaksanaannya di lingkungan Peradilan Agama pada tahun 1983, yaitu sesudah penandatanganan Surat Keputusan Bersama (SKB) Ketua Mahkamah Agung dengan Menteri Agama RI No. 01, 02, 03, dan 04/ SK/1-1983 dan No.1,2,3, dan 4 tahun 1983. Keempat SKB dimaksud adalah jalan pintas sambil menunggu keluarnya Undang-Undang tentang Susunan, Kekuasaan dan Acara pada Peradilan Agama yang menjadi peraturan pelaksanaan Undang-Undang Nomor 14 Tahun 1970 bagi lingkungan Peradilan Agama yang pada saat itu masih sedang dalam proses penyusunan yang intensif(sekarang Undang-Undang Nomor 41 Tahun 2004), sehingga sesuai dengan fungsi Mahkamah Agung RI terhadap jalannya peradilan di semua lingkungan Peradilan Agama perlu mengadakan KHI yang selama ini menjadikan hukum positif di Pengadilan Agama.

Pada akhir dekade 1980-an terdapat dua peristiwa penting berkenaan dengan perkembangan hukum dan peradilan Islam di Indonesia. Pertama, pada 25 Pebruari 1988, ulama Indonesia telah menerima tiga rancangan buku KHI. Rancangan kompilasi itu, pada 10 Juni 1991 mendapat legalisasi pemerintah dalam bentuk Instruksi Presiden kepada Menteri Agama untuk digunakan oleh instansi pemerintah dan oleh masyarakat yang memerlukannya. Instruksi itu dilaksanakan dengan Keputusan Menteri Agama Nomor 154 tanggal 22 Juli 1991. Kedua, pada 29 Desember 1989 disahkan dan diundangkan Undang-Undang Nomor 7 Tahun 1989 tentang Peradilan Agama.

Kedua peristiwa itu merupakan suatu rangkaian yang saling berhubungan dan saling melengkapi. KHI disusun dan dirumuskan untuk mengisi kekosongan hukum substansial, yang diberlakukan pada pengadilan dalam lingkungan Peradilan Agama. Sedangkan dalam Undang-Undang Nomor 7 Tahun 1989, antara lain diatur tentang kekuasaan pengadilan dalam lingkungan Peradilan Agama. Dengan demikian, secara yuridis hukum Islam di bidang perkawinan, kewarisan dan perwakafan menjadi hukum positif tertulis dalam sistem hukum nasional (tata

24 Rofq, Hukum......, h. 76. 
hukum Indonesia $)^{25}$.

Adapun tujuan perumusan KHI di Indonesia adalah menyiapkan pedoman yang seragam (unifikasi) bagi hakim Pengadilan Agama dan menjadi hukum positif yang wajib dipatuhi oleh seluruh bangsa Indonesia yang beragama Islam. Dengan demikian, diharapkan nantinya tidak ada lagi kesimpangsiuran keputusan Pengadilan Agama. Hal seperti itu sering terjadi kasus yang sama akan tetapi dengan keputusan yang berbeda. Hal ini terjadi sebagai akibat darireferensi hakim kepada kitab-kitab fikih yang sesuai dengan karakteristiknya sebagai rumusan para fuqaha' yang sangat dipengaruhi oleh situasi dan lingkungan di mana fuqaha' itu berada. Dengan tersusunnya KHI yang merupakan peraturan hukum Islam yang sesuai dengan kondisi kebutuhan hukum dan kesadaran hukum umat Islam di Indonesia. Ia bukan merupakan mazhab baru dalam fikih Islam, melainkan merupakan wujud dan penerapan berbagai mazhab fikih yang ada untuk menjawab persoalan yang ada diIndonesia sesuai dengan kesadaran hukum masyarakat Islam Indonesia.

\section{Pengaruh Mazhab Fiqh terhadap Undang-Undang Nomor 41 Tahun 2004 tentang Wakaf}

Sebagaimana disebutkan sebelumnya bahwa Undang-Undang Nomor 41 Tahun 2004 tentang Wakaf merupakan salah satu dari regulasi wakaf di Indonesia, di samping regulasi wakaf lainnya, termasuk Peraturan Pemerintah (PP), Peraturan Menteri Agama (PMA), dan sebagainya. Sebagai sebuah undang-undang tentu ia merupakan produk politik yang tidak terlepas dari latarbelakang pelaku politik itu sendiri. Indonesia sebagaimana sudah dimaklumi merupakan negara dengan penduduk muslim terbanyak di dunia bahkan melebihi negara-negara Islam lainnya. Dengan jumlah penduduknya yang mayoritas muslim tentu produk politiknya juga akan banyak dipengaruhi.

Dalam Islam terdapat banyak aliran dan mazhab, baik dalam bidang kalam, maupun fikih. Dalam bidang fikih dikenal berbagai macam mazhab, yang sebagiannya masih tetap eksis dan sebagian lainnya telah "ditelan" oleh zaman. Di antara mazhab fikih yang masih eksis sampai sekarang yaitu mazhab sunni (ablal-sunnah wa al-jamah) dan mazhab syìi (syi’ah). Dalam mazhab sunni juga terdapat berbagai macam mazhab, yaitu Hanafi, Maliki, Syafi'i, dan Hanbali. Keempat mazhab inilah yang berkembang di seluruh dunia termasuk di Indonesia meskipun berbeda-beda dalam prosentasenya. Mazhab Hanafi berkembang pesat di Iraq dan kemudian menyebar ke Azarbaijan, Sijistan, Khurrosan, Turki, Siria, Libanon, Yordania, dan sekarang berkembang di Afganistan, Pakistan, India,

25 http:/ / tintapenaamhy.blogspot.co.id/2013/12/polemik-kompilasi-hukum-islam-di.html, diakses 30 Desember 2019 
dan Mesir. Mazhab Maliki berkembang di Hijaz kemudian menyebar ke benua Afrika khususnya Maroko dan Andalus. Mazhab Syafi'i berkembang di Mesir kemudian menyebar ke Iraq dan dari Iraq menyebar ke Khurrosan, Yaman, Hijaz, Indonesia dan sebagian India. Sedangkan mazhab Hanbali banyak berkembang di Arab Saudi ${ }^{26}$.

Namun demikian, tidak berarti bahwa mazhab selain mazhab Syafi'i tidak berkembang di Indonesia meskipun memang mazhab yang paling banyak diikuti di Indonesia adalah mazhab Syafi'i. Undang-Undang Nomor 41 Tahun 2004 tentang Wakaf juga tidak luput dari pengaruh dari mazhab-mazhab tersebut.Berikut akan dijelaskan secara terperinci pasal-pasal yang dipengaruhi oleh mazhab-mazhab sunni tersebut. Undang-Undang Nomor 41 Tahun 2004 tentang Wakaf terdiri atas 11 bab dan 71 pasal, namun pasal yang dijadikan sebagai obyek penelitian ini yaitu Pasal 1, 6, 7, 8, 9, 16, 22, 28, dan Pasal 40, walaupun terdapat beberapa pasal yang terdiri atas beberapa point.

Pasal 1 tentang definisi Wakaf, Wakif, Ikrar Wakaf, Nazhir, Harta Benda Wakaf, Pejabat Pembuat AIW, BWI, Pemerintah, dan Menteri. Pasal 1 UndangUndang Nomor 41 Tahun 2004 tentang Wakaf merupakan Ketentuan Umum. Dalam pasal ini terdapat empat point yang dipilih untuk dijadikan sebagai obyek penelitian yaitu definisi wakaf, wakif, nazhir, dan harta benda wakaf. Dalam Pasal 1 disebutkan tentang definisi wakaf bahwa; "wakaf adalah perbuatan hukum wakif untuk memisahkan dan/atau menyerabkan sebagian harta benda miliknya untuk dimanfaatkan selamany a atau untuk jangka waktu tertentu sesuai dengan kepentingan guna keperluan ibadah dan/atau kesejahteraan umum menurut syariah". Apabila diperhatikan definisi wakaf tersebut, maka dapat disimpulkan bahwa: wakaf adalah suatu perbuatan hukum dari pewakaf (wakif) untuk menyerahkan semua atau sebagian hartanya untuk dimanfaatkan; pemanfaatan harta wakaf tersebut berlangsung selamanya atau untuk jangka waktu tertentu; peruntukan harta wakaf tersebut digunakan untuk keperluan ibadah atau untuk kesejahteraan umum.

Sementara itu, Wahbah al-Zuhaili dalam al-Figh al-Islamy wa Adillatuh mengungkapkan beberapa definisi wakaf menurut para ulama' mazhab: Hanafiyah; wakaf adalah menahan materi benda (al-'ain) milik wakif dan menyedekahkannya atau mewakafkan manfaatnya kepada siapapun yang diinginkan untuk tujuan kebajikan; Malikiyah, wakaf adalah menjadikan manfaat suatu harta yang dimiliki (walaupun pemiliknya dengan cara sewa) untuk diberikan kepada orang yang berhak dengan satu akad (shigat) dalam jangka waktu tertentu sesuai keinginan

26 Fakhruddin, Intellectual Network, Sejarah dan Pemikiran Empat Imam Mazhab Fikih, (Malang: UIN-Malang Pres, 2009), h. 8. 
wakif; Syafi'iyyah, wakaf adalah menahan harta yang bisa memberi manfaat serta kekal materi bendanya (al-'ain) dengan cara memutuskan pengelolaan yang dimiliki oleh wakif untuk diserahkan kepada nazhir yang dibolehkan oleh syariah; dan Hanabilah, wakaf adalah menahan asal harta (tanah) dan menyedekahkan manfaat yang dihasilkan ${ }^{27}$.

Dengan memperhatikan definisi wakaf dalam Undang-Undang Nomor 41 Tahun 2004 tentang Wakaf dan definisi wakaf yang disampaikan oleh empat mazhab, maka dapat dikatakan terdapat pengaruh mazhab Hanafi, Maliki, Syafi'i, dan Hanbali terhadap pasal 1 ini. Adapun wakifdalam kelanjutan Pasal 1 ini disebutkan bahwa "Wakif adalah pihak yang mewakafkan harta benda miliknya". Oleh karena definisi wakif adalah pihak yang mewakafkan harta benda miliknya, maka tentu ini sesuai dengan pendapat Hanafi, Maliki, Syafi'i, dan Hanbali. Sementara itu definisi nazhir dalam Pasal 1 ini diartikan sebagai "pihak yang menerima harta benda wakaf dari wakif untuk dikelola dan dikembangkan sesuai dengan peruntukannya".Definisi nazhir ini merupakan definisi yang disampaikan oleh Hanafi, Maliki, Syafi'i, dan Hanbali, akan tetapi dipengaruhi juga oleh fikih kontemporer karena badan usaha juga dimasukkan ke dalam kategori nazhir.

Dalam Pasal 6 Undang-Undang Nomor 41 Tahun 2004 tentang Wakaf dijelaskan tentang Unsur Wakaf. Dalam pasal 6 ini dijelaskan bahwa wakaf dilaksanakan dengan memenuhi unsur wakaf sebagai berikut: wakif; nazhir; harta benda wakaf; ikrar wakaf; peruntukan harta benda wakaf; dan jangka waktu wakaf. Dalam pandangan empat mazhab terdapat perbedaan pendapat tentang unsur-unsur wakaf yaitu antara Hanafi dan tiga mazhab lainnya (Maliki, Syafi'i, dan Hanbali). Menurut Hanafi bahwa yang menjadi unsur atau rukun wakaf hanya satu yaitu shigat. Sementara menurut Maliki, Syafi'i, dan Hanbali bahwa unsur atau rukun wakaf ada empat, yaitu wakif (pihak yang mewakafkan), mauqufalaih (pihak yang menerima wakaf), mauquf (benda atau barang yang diwakafkan), dan shigat. Dengan demikian, maka dapat dikatakan bahwa pasal ini dipengaruhi oleh mazhab Maliki, Syafi'i, dan Hanbali.

Pasal 7dan 8 Undang-Undang Nomor 41 Tahun 2004 tentang Wakaf dijelaskan tentang Wakif. Dalam pasal 7 dijelaskan bahwa:"wakif meliputi tiga pihak, yaitu perseorangan, organisasi, dan badan hukum". Sedangkan, pasal 8 menjelaskan bahwa wakif perseorangan sebagaimana dimaksud dalam pasal 7 huruf a hanya dapat melakukan wakaf apabila memenuhi persyaratan, yaitu: dewasa; berakal sehat; tidak terhalang melakukan perbuatan hukum, dan pemilik sah harta benda wakaf.

27 Wahbah al-Zuhaili, al-Figh al-Islamy wa Adillatuh (Dar al-Fikr: Beirut, 2004), h. 7599-7602. 
Sementara itu, ayat 2 menjelaskan bahwa wakif organisasi sebagaimana dimaksud dalam Pasal 7 hurufb hanya dapat melakukan wakaf apabila memenuhi ketentuan organisasi untuk menawarkan harta benda wakaf milik organisasi sesuai dengan anggaran dasar organisasi yang bersangkutan. Adapun ayat 3 menjelaskan bahwa wakif badan hukum sebagaimana dimaksud dalam Pasal 7 ayat c hanya dapat melakukan wakaf apabila memenuhi ketentuan badan hukum untuk mewakafkan harta benda wakaf milik badan hukum sesuai dengan anggaran dasar badan hukum yang bersangkutan.

Dalam fikih wakaf disebutkan bahwa wakif adalah orang atau pihak yang mewakafkan harta bendanya. Para imam mazhab fikih yang empat memberikan syarat-syarat bagi wakif, yaitu merdeka, milik sendiri, berakal, baligh,dan cakap (rasyid). Dengan melihat persyaratan wakif dari Undang-undang tersebut, maka dapat dikatakan bahwa pasal ini dipengaruhi oleh Hanafi, Maliki, Syafi'i, dan Hanbali.

Pasal 9, 10, 11, 12, 13, dan 14 ini merupakan pasal yang menjelaskan tentang Nazhir. Dalam pasal 9 disebutkan bahwa nazhir meliputi: perseorangan; organisasi; dan badan hukum. Pasal 9 ini dijelaskan oleh pasal 10 yaitu bahwa: (1) Perseorangan sebagaimana dimaksud dalam Pasal 9 huruf a hanya dapat menjadi nazhir apabila memenuhi persyaratan: warga negara Indonesia; beragama Islam; dewasa; amanah; mampu secara jasmani dan rohani, dan tidak terhalang melakukan perbuatan hukum.

(2) Organisasi sebagaimana dimaksud dalam Pasal 9 huruf b hanya dapat menjadi nazhir apabila memenuhi persyaratan: pengurus organisasi yang bersangkutan memenuhi persyaratan nazhir perseorangan sebagaimana dimaksud pada ayat (1); dan organisasi yang bergerak di bidang sosial, pendidikan, kemasyarakatan, dan/ atau keagamaan Islam. (3) Badan hukum sebagaimana dimaksud dalam Pasal 9 huruf $\mathrm{c}$ hanya dapat menjadi nazhir apabila memenuhi persyaratan: pengurus badan hukum yang bersangkutan memenuhi persyaratan nazhir perseorangan sebagaimana dimaksud pada ayat (1); dan badan hukum Indonesia yang dibentuk sesuai dengan peraturan perundang-undangan yang berlaku; dan badan hukum yang bersangkutan bergerak di bidang sosial, pendidikan, kemasyarakatan, dan/ atau keagamaan Islam. Adapun Pasal 11 menjelaskan tentang tugas nazhir, yaitu: melakukan pengadministrasian harta benda wakaf; mengelola dan mengembangkan harta benda wakaf sesuai dengan tujuan, fungsi, dan peruntukannya; mengawasi dan melindungi harta benda wakaf; dan melaporkan pelaksanaan tugas kepada Badan Wakaf Indonesia. 
Kemudian Pasal 12 menjelaskan tentang imbalan bagi nazhir. Dalam pasal 12 ini disebutkan bahwa dalam melaksanakan tugas sebagaimana dimaksud dalam Pasal 11, nazhir dapat menerima imbalan dari hasil bersih atas pengelolaan dan pengembangan harta benda wakaf yang besarnya tidak melebihi 10\% (sepuluh persen). Selanjutkan Pasal 13 menjelaskan tentang pembinaan nazhir yang dijelaskan lebih lanjut dalam Pasal 14. Dalam Pasal 14 ini dijelaskan bahwa; (1) dalam rangka pembinaan sebagaimana dimaksud dalam Pasal 13, nazhir harus terdaftar pada Menteri dan Badan Wakaf Indonesia. (2) ketentuan lebih lanjut mengenai nazhir sebagaimana dimaksud dalam Pasal 9, Pasal 10, Pasal 11, Pasal 12, dan Pasal 13, diatur dengan Peraturan Pemerintah. Dengan memperhatikan pasalpasal yang menjelaskan tentang nazhir di atas, maka dapat dikatakan bahwa pasal ini dipengaruhi oleh Hanafi, Maliki, Syafi'i, dan Hanbali, di samping dipengaruhi juga oleh fikih kontemporer.

Pasal 15 dan 16 ini menjelaskan tentang harta benda wakaf. Menurut pasal 15 bahwa harta benda wakaf hanya dapat diwakafkan apabila dimiliki dan dikuasai oleh wakif secara sah. Sedangkan Pasal 16 adalah penjelas Pasal 15, yaitu bahwa: (1) harta benda wakaf terdiri dari atas benda tidak bergerak, dan benda bergerak. (2) benda tidak bergerak sebagaimana dimaksud pada ayat (1) huruf a meliputi: hak atas tanah sesuai dengan ketentuan peraturan perundang-undangan yang berlaku baik yang sudah maupun yang belum terdaftar; bangunan atau bagian bangunan yang berdiri di atas tanah sebagaimana dimaksud pada huruf a; tanaman dan benda lain yang berkaitan dengan tanah; hak milik atas satuan rumah susun sesuai dengan ketentuan peraturan perundang-undangan yang berlaku; benda tidak bergerak lain sesuai dengan ketentuan syariah dan peraturan perundangundangan yang berlaku. (3) benda bergerak sebagaimana dimaksud pada ayat (1) huruf $\mathrm{b}$ adalah harta benda yang tidak bisa habis karena dikonsumsi, meliputi: uang; logam mulia; surat berharga; kendaraan; hak atas kekayaan intelektual; hak sewa, dan benda bergerak lain sesuai dengan ketentuan syariah dan peraturan perundang-undangan yang berlaku.

Dengan memperhatikan Pasal 15 dan 16 ini yang membahas tentang harta benda wakaf, maka dapat dibedakan pengaruh mazhab yang empat terhadap kedua pasal ini. Pasal 15 dipengaruhi oleh empat mazhab, sedangkan Pasal 16 dipengaruhi oleh tiga mazhab saja yaitu Maliki, Syafi'i, dan Hanbali. Hal ini disebabkan karena mazhab Hanafi tidak membolehkan harta benda wakaf yang bergerak dengan alasan bahwa di antara syarat wakaf adalah ta'bid (untuk selamanya), sedangkan dalam wakaf benda bergerak tidak demikian. 
Pasal 22 UU Nomor 41/2004 tentang Wakaf membahas tentang Peruntukan Harta Benda Wakaf. Menurut Pasal 22 ini bahwa dalam rangka mencapai tujuan dan fungsi wakaf, harta benda wakaf hanya dapat diperuntukan bagisarana dan kegiatan ibadah, sarana dan kegiatan pendidikan serta kesehatan, bantuan kepada fakir miskin, anak terlantar, yatim piatu, bea siswa, kemajuan dan peningkatan ekonomi umat, dan/atau kemajuan kesejahteraan umum lainnya yang tidak bertentangan dengan syariah dan peraturan perundang-undangan.

Dengan memperhatikan penjelasan Pasal 22 ini, maka dapat dikatakan bahwa pasal ini dipengaruhi oleh Hanafi, Maliki, Syafi'i, dan Hanbali. Hal ini karena empat mazhab menjelaskan bahwa harta benda wakaf digunakan sesuai dengan yang disyaratkan oleh wakif dan tentu untuk hal-hal yang tidak bertentangan dengan hukum Islam.

Pasal 28 Undang-Undang Nomor 41 Tahun 2004 menjelaskan tentang Wakaf Benda Bergerak Berupa Uang. Menurut Pasal 28 ini bahwa; "Wakif dapat mewakafkan benda bergerak berupa uang melalui lembaga keuangan syariah yang ditunjuk oleb Menteri". Sementara itu menurut mazhab Hanafi bahwa wakaf uang boleh sebagai pengecualian atas dasar istihsan bi al-urfkarena sudah banyak dilakukan oleh masyarakat. Begitu juga dengan ketiga mazhab fikih lainnya mengatakan bahwa wakaf tunai atau uang hukumnya boleh.

Pasal 40 menjelaskan tentang Perubahan Status Harta Benda Wakaf. Dalam Pasal 40 ini dijelaskan bahwa harta benda wakaf yang sudah diwakafkan dilarang: dijadikan jaminan; disita; dihibahkan; dijual; diwariskan; ditukar, atau dialihkan dalam bentuk pengalihan hak lainnya. Pasal ini dipengaruhi oleh mazhab Maliki dan Syafi'i karena kedua mazhab ini tidak membolehkan harta benda wakaf untuk diperjualbelikan. Sementara itu, menurut mazhab Hanafi dan Hanbali mengatakan bahwa harta benda wakaf boleh diperjualbelikan.

Dengan demikian, maka pengaruh mazhab yang empat terhadap UndangUndang Nomor 41 Tahun 2004 tentang Wakaf terdiri atas: Mazhab hanafi sebesar 11 point; Mazhab Maliki sebesar 14 point; Mazhab Syafi'i sebesar 14 point, dan Mazhab Hanbali sebesar 12 point. Apabila jumlah point tersebut dimasukkan ke dalam rumus sesuai dengan rumus yang digunakan, maka dapat digambarkan sebagai berikut:

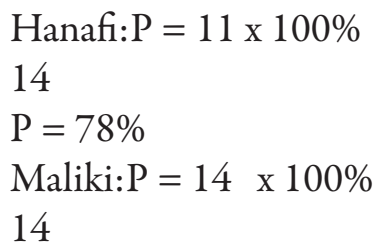




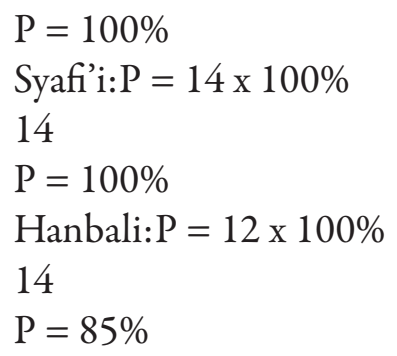

Untuk lebih jelasnya dapat dilihat dalam tabel berikut:

Tabel 1. Pengaruh Empat Mazhab Terhadap UUNomor 41/2004 tentang Wakaf

\begin{tabular}{|c|c|c|c|}
\hline Pasal & Tema & Mazhab & Hasil \\
\hline \multirow[t]{3}{*}{ Pasal 1} & Definisi wakaf & $\begin{array}{l}\text { Hanafi, Maliki, Syafi'i, } \\
\text { dan Hanbali }\end{array}$ & \multirow{3}{*}{$\begin{array}{l}\text { Sesuai dengan rumus } \\
\text { yang digunakan yaitu: } \\
\mathrm{P}=\underline{\mathrm{f}} \times 100 \% \\
\mathrm{~N} \\
\text { Keterangan: } \\
\mathrm{P}=\text { Prosentase } \\
\mathrm{F}=\text { frekwensi pada } \\
\text { klasifikasi } \\
\mathrm{N}=\text { Jumlah frekwensi } \\
\text { dari seluruh klasifikasi } \\
\text { Maka dapat } \\
\text { disimpulkan: }\end{array}$} \\
\hline & Definisi wakif & $\begin{array}{l}\text { Hanafi, Maliki, Syafi'i, } \\
\text { dan Hanbali }\end{array}$ & \\
\hline & Definisi nazhir & $\begin{array}{l}\text { Hanafi, Maliki, Syafi'i, } \\
\text { dan Hanbali }\end{array}$ & \\
\hline Pasal 6 & Unsur wakaf & Maliki, Syafi'i, Hanbali & \multirow{4}{*}{$\begin{array}{l}\text { Hanafi: } \\
P=\frac{11}{14} \times 100 \% \\
P=78 \%\end{array}$} \\
\hline $\begin{array}{l}\text { Pasal } 7 \\
\text { dan } 8\end{array}$ & Wakif & $\begin{array}{l}\text { Hanafi, Maliki, Syafi'i, } \\
\text { dan Hanbali }\end{array}$ & \\
\hline $\begin{array}{l}\text { Pasal } \\
9,10, \text { dan }\end{array}$ & Nazhir & $\begin{array}{l}\text { Hanafi, Maliki, Syafi'i, } \\
\text { dan Hanbali }\end{array}$ & \\
\hline & & & \\
\hline Pasal 15 & $\begin{array}{l}\text { Harta benda } \\
\text { wakaf }\end{array}$ & $\begin{array}{l}\text { Hanafi, Maliki, Syafi'i, } \\
\text { dan Hanbali }\end{array}$ & \multirow{2}{*}{$\begin{array}{l}\text { Maliki: } \\
\mathrm{P}=\frac{14}{14} \times 100 \% \\
\mathrm{P}=100 \%\end{array}$} \\
\hline Pasal 16 & $\begin{array}{l}\text { Harta benda } \\
\text { wakaf }\end{array}$ & Maliki, Syafi'i, Hanbali & \\
\hline Pasal 22 & $\begin{array}{l}\text { Peruntukan } \\
\text { harta benda } \\
\text { wakaf }\end{array}$ & $\begin{array}{l}\text { Hanafi, Maliki, Syafi'i, } \\
\text { dan Hanbali }\end{array}$ & $\begin{array}{l}\text { Syafi'i: } \\
\mathrm{P}=\underline{14} \times 100 \% \\
14 \\
\mathrm{P}=100 \%\end{array}$ \\
\hline Pasal 28 & $\begin{array}{l}\text { Wakaf benda } \\
\text { bergerak } \\
\text { berupa uang }\end{array}$ & $\begin{array}{l}\text { Hanafi, Maliki, Syafi'i, } \\
\text { dan Hanbali }\end{array}$ & \multirow{2}{*}{$\begin{array}{l}\text { Hanbali: } \\
\mathrm{P}=\underline{12} \times 100 \% \\
14 \\
\mathrm{P}=85 \%\end{array}$} \\
\hline Pasal 40 & $\begin{array}{l}\text { Perubahan } \\
\text { status harta } \\
\text { benda wakaf }\end{array}$ & Maliki dan syafi'i & \\
\hline
\end{tabular}

Sumber: data diolah 


\section{Pengaruh Mazhab Fiqh terhadap Kompilasi Hukum Islam}

Sebagaimana Undang-Undang Nomor 41 Tahun 2004 tentang Wakaf yang mendapat pengaruh dari mazhab yang empat, maka KHI juga dipengaruhi oleh keempat mazhab tersebut. KHI terdiri atas tiga buku. Buku pertama membahas tentang Hukum Perkawinan, buku kedua menjelaskan tentang Hukum Kewarisan, dan buku ketiga tentang Hukum Perwakafan. Oleh karena penelitian ini tentang wakaf, maka dalam penelitian ini yang dijadikan obyek penelitian adalah buku ketiga. Dalam bab perwakafan ini terdiri atas 5 bab dan 15 pasal,yaitu Pasal 215, $216,217,218,219,220,221,222,223,224,225,226,227$, dan 228. Namun tidak semua pasal itu akan dibahas, hanya beberapa pasal saja yang diambil yaitu Pasal 215, 216, 217, dan 219tapi terdiri atas 9 point karena ada beberapa pasal yang terdiri atas beberapa point penjelasan.

Dalam pasal 215 KHI dibahas tentang Ketentuan Umum yang terdiri atas tujuh point, yaitu wakaf, wakif, ikrar, benda wakaf, nazhir, pejabat pembuat akta ikar wakaf, dan pejabat pembuat akta ikrar wakaf. Dalam penelitian ini hanya diambil empat point saja yaitu definisi wakaf, waqif, benda wakaf, nazhir. Definisi wakaf yang disampaikan dalam KHI ini yaitu bahwa wakaf adalah: "perbuatan bukum seseorang atau kelompok orang atau badan hukum yang memisabkan sebagian dari benda miliknya dan melembagakannya untuk selama-lamanya guna kepentingan ibadat atau keperluan umum lainnya sesuai dengan ajaran Islam".

Apabila diperhatikan definisi wakaf tersebut, maka bisa dikatakan bahwa pasal ini dipengaruhi oleh mazhab yang empat, karena menurut keempat mazhab fikih bahwa wakaf diberikan selamanya untuk kepentingan umum. Adapun definisi wakif dalam KHI ini merupakan pengaruh dari keempat mazhab dimana dijelaskan bahwa wakif adalah orang atau lembaga yang menyerahkan harta benda wakafnya. Sementara itu harta wakaf disebutkan bahwa benda wakaf adalah segala benda baik benda bergerak atau tidak bergerak uang memiliki daya tahan yang tidak hanya sekali pakai dan bernilai menurut ajaran Islam. Dengan memperhatikan penjelasan pasal ini, maka pasal ini dipengaruhi oleh mazhab Maliki, Syafi'i, dan Hanbali. Sedangkan nazhir didefinisikan sebagai kelompok orang atau badan hukum yang diserahi tugas pemeliharaan dan pengurusan benda wakaf. Point ini juga dipengaruhi oleh keempat mazhab fikih.

Pasal 216 KHI menjelaskan tentangFungsi Wakaf. Disebutkan dalam pasal ini bahwa;"fungsi wakaf adalah mengekalkan manfaat benda wakaf sesuai dengan tujuan wakaf". Dengan melihat fungsi yang disampaikan oleh empat mazhab, maka pasal 216 ini dipengaruhi oleh keempat mazhab fikih. Hal ini karena mazhab empat mengatakan bahwa wakaf diserahkan untuk diambil manfaatnya untuk kebaikan dan hal-hal yang tidak bertentangan dengan Islam. 
Pasal 217 KHI menjelaskan tentang Unsur-unsur dan Syarat-syarat Wakaf. Dalam penjelasannya disebutkan bahwa: (1) badan-badan hukum Indonesia dan orang atau orang-orang yang telah dewasa dan sehat akalnya serta yang oleh hukum tidak terhalang untuk melakukan perbuatan hukum, atas kehendak sendiri dapat mewakafkan benda miliknya dengan memperhatikan peraturan perundangundangan yang berlaku. (2) dalam hal badan-badan hukum, maka yang bertindak untuk dan atas namanya adalah pengurusnya yang sah menurut hukum. (3) benda wakaf sebagaimana dimaksud dalam Pasal 215 ayat (4) harus merupakan benda milik yang bebas dari segala pembebanan, ikatan, sitaan, dan sengketa.

Dengan memperhatikan penjelasan pasal ini, maka pasal ini mendapat pengaruh dari empat mazhab fikih.Para imam mazhab fikih yang empat memberikan syarat-syarat bagi wakif yaitu merdeka, milik sendiri, berakal, baligh, dan cakap (rasyid).

Pasal 219 ini membahas tentang Nazhir. Dalam penjelasannya tentang nazhir ini disebutkan bahwa; (1) badan-badan hukum Indonesia dan orang atau orang-orang yang telah dewasa dan sehat akalnya serta yang oleh hukum tidak terhalang untukmelakukan perbuatan hukum, atas kehendak sendiri dapat mewakafkan benda miliknya dengan memperhatikan peraturan perundangundangan yang berlaku. (2) dalam hal badan-badan hukum, maka yang bertindak untuk dan atas namanya adalah pengurusnya yang sah menurut hukum. (3) benda wakaf sebagaimana dimaksud dalam Pasal 215 ayat (4) harus merupakan benda milik yang bebas dari segala pembebanan, ikatan, sitaan, dan sengketa. Dengan memperhatikan pasal yang menjelaskan tentang Nazhir ini, maka dapat dikatakan bahwa pasal ini dipengaruhi oleh keempat mazhab fikih.

Dengan demikian, maka pengaruh mazhab yang empat terhadap KHI sesuai dengan rumus yang digunakan adalah sebagai berikut:

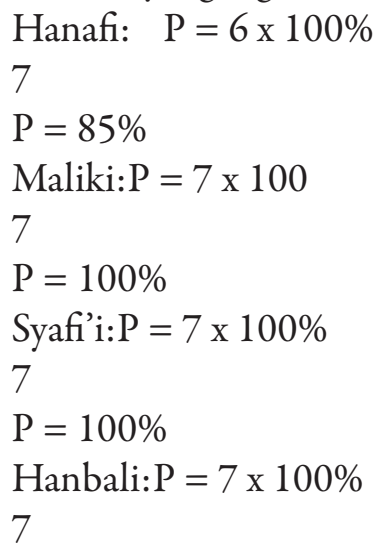


$\mathrm{P}=100 \%$

Untuk lebih jelasnya bisa dilihat dalam tabel berikut:

Tabel 2. Pengaruh Empat Mazhab

Terhadap Kompilasi Hukum Islam

\begin{tabular}{|c|c|c|c|}
\hline Pasal & Tema & Mazhab & \multirow{13}{*}{$\begin{array}{l}\text { Hasil } \\
\text { Sesuai dengan rumus yang } \\
\text { digunakan yaitu: } \\
\mathrm{P}=\underline{\mathrm{f}} \times 100 \% \\
\text { Keterangan: } \\
\mathrm{P}=\text { Prosentase } \\
\mathrm{F}=\text { frekwensi pada klasifikasi } \\
\mathrm{N}=\text { Jumlah frekwensi dari } \\
\text { seluruh klasifikasi } \\
\text { Maka dapat disimpulkan: } \\
\text { Hanafi: } \\
\mathrm{P}=\underline{6} \times 100 \% \\
7 \\
\mathrm{P}-\mathrm{e} 50\end{array}$} \\
\hline \multirow[t]{11}{*}{ Pasal 215} & \multirow[t]{3}{*}{ Definisi wakaf } & Hanafi, Maliki, & \\
\hline & & Syafi'i, dan & \\
\hline & & Hanbali & \\
\hline & \multirow{4}{*}{ Definisi wakif } & Hanafi Maliki & \\
\hline & & finall, & \\
\hline & & Sydil 1, Uall & \\
\hline & & Hanbali & \\
\hline & Benda wakaf & $\begin{array}{l}\text { Maliki, Syafi'i, } \\
\text { dan Hanbali }\end{array}$ & \\
\hline & \multirow[t]{3}{*}{ Nazhir } & Hanafi, Maliki, & \\
\hline & & Svafi'i, dan & \\
\hline & & Hanhali & \\
\hline \multirow{3}{*}{ Pasal 216} & \multirow{3}{*}{ Fungsi wakaf } & 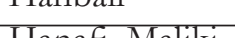 & \\
\hline & & $\begin{array}{l}\text { Hanaf, Malık1, } \\
\text { Syafi'i, dan }\end{array}$ & $\mathrm{P}=85 \%$ \\
\hline & & Hanbali & \multirow{4}{*}{$\begin{array}{l}\text { Maliki: } \\
P=\frac{7}{7} \times 100 \\
P=100 \%\end{array}$} \\
\hline \multirow[t]{3}{*}{ Pasal 217} & \multirow{3}{*}{$\begin{array}{l}\text { Unsur dan } \\
\text { syarat wakaf }\end{array}$} & Hanafi, Maliki, & \\
\hline & & Syafi'i, dan & \\
\hline & & Hanbali & \\
\hline \multirow[t]{8}{*}{ Pasal 225} & \multirow{8}{*}{$\begin{array}{l}\text { Perubahan } \\
\text { Benda Wakaf }\end{array}$} & Hanafi, Maliki, & Syafi'j. \\
\hline & & Syafi'i, dan & $\mathrm{P}=\underline{7} \times 100 \%$ \\
\hline & & Hanbali & \\
\hline & & & $P=100 \%$ \\
\hline & & & Hanbali: \\
\hline & & & $\mathrm{P}=\underline{I} \times 100 \%$ \\
\hline & & & 7 \\
\hline & & & $\mathrm{P}=100 \%$ \\
\hline
\end{tabular}

Sumber: data diolah

\section{Simpulan}

Setelah melakukan pemaparan hasil penelitian dan analisis data sesuai dengan permasalahan yang diajukan di awal, maka simpulan yang diperoleh bahwa pengaruh mazhab Hanafi, Maliki, Syafi'i, dan Hanbali terhadap UndangUndang Nomor 41 Tahun 2004 tentang Wakaf terdiri atas pengaruh mazhab Hanafi sebanyak 78\%, mazhab Maliki sebanyak 100\%, mazhab Syafi'i sebanyak 100\%, dan mazhab Hanbali sebanyak 85\% dari 11 pasal yang dijadikan obyek penelitian ini. Sedangkan, pengaruh mazhab empat mazhab tersebut terhadap 
Kompilasi Hukum Islam sebanyak 85\% untuk mazhab Hanafi, mazhab Maliki sebanyak 100\%, mazhab syafi'i sebanyak 100\%, dan mazhab Hanbali sebanyak $100 \%$ dari 5 pasal yang dijadikan obyek penelitian ini. Adapun perbandingan pengaruh mazhab yang empat antara Undang-Undang Nomor 41 Tahun 2004 tentang Wakaf dan Kompilasi Hukum Islam yaitu mazhab Maliki dan Syafi'i lebih banyak mempengaruhi Undang-undang tersebut sebanyak 100\% sedangkan Kompilasi Hukum Islam lebih banyak dipengaruhi oleh mazhab Maliki, Syafi'i, dan Hanbali sebanyak masing-masing 100\%.

\section{Daftar Pustaka}

\section{Buku}

Athoillah, M. Hukum Wakaf. Bandung: Yrama Widya, 2014.

Aziz Dahlan, Abdul et al., Ensiklopedi Hukum Islam. Jakarta: PT. Ichtiar Baru Van Hoeve, 1996.

Azizy, A. Qodri. Reformasi Bermazhab, Sebuah Ikhtiar Menuju Ijtihad Sesuai Saintifik-Modern.Jakarta: Teraju, 2003.

Badan Wakaf Indonesia. Manajemen Wakaf di Era Modern. Jakarta: Badan Wakaf Indonesia, 2013.

Direktorat Pemberdayaan Wakaf. Strategi Pengembangan Wakaf Tunai di Indonesia. Jakarta: Departemen Agama, 2007.

Fakhruddin. Intellectual Network, Sejarah dan Pemikiran Empat Imam Mazhab Fikih. Malang: UIN-Malang Pres, 2009.

Iskandar. Metodologi Penelitian Pendidikan dan Sosial, Kuantitatif dan Kualitatif. Jakarta: Gaung Persada Press, 2008.

L. Esposito John,ed., Ensiklopedi Oxford Dunia Islam Modern. Bandung: Mizan, 2001.

Lis Sulistiani, Siska. Pembaharuan Hukum Wakaf di Indonesia. Bandung: Refika Aditama, 2017.

Mubarok, Jaih. Wakaf Produktif. Bandung: Simbiosa Rekatama Media, 2008.

Rofiq, Ahmad. Hukum Islam di Indonesia. Yogyakarta: Gama Media, 2001.

Sudirman. TQM untuk Wakaf. Malang: UIN Malang Press, 2013. 
Wahbah al-Zuhaili. al-Figh al-Islamy wa Adillatuh. Beirut: Dar al-Fikr, 2004.

Wajdy, Farid dan Mursyid. Wakaf dan Kesejahteraan Umat. Yogyakarta: Pustaka Pelajar, 2007.

\section{Artikel}

Dadan Suganda, Asep. "Konsep WakafTunai." Jurnal Islamiconomic. Vol. 5, Nomor 2: 2014 .

Faradis, Jauhar, M. Yazid Affandi, dan Slamet Khilmi. "Manajemen Fundraising Wakaf Produktif: Perbandingan Wakaf Selangor (PWS) Malaysia dan Badan Wakaf Indonesia." Jurnal Asy-Syir'ah, Vol. 49. Nomor 2: Desember 2015.

Fauza, Nilna, "Rekonstruksi Pengelolaan Wakaf: Belajar Pengelolaan Wakaf dari Bangladesh dan Malaysia." Jurnal Universum. Vol. 01: 2015.

Hadi, Solikhul. "Pemberdayaan Ekonomi Melalui Wakaf." Jurnal Zakat dan Wakaf. Vol. 4, Nomor 2: 2017.

Sofyan, Muhammad. "Wakaf antara Peluang dan Tantangan (Studi Konstruktif Bentuk Wakaf).Jumal Asas.Vol. 5. Nomor 1: 2013.

Sulfinadia, Hamda. "Kontroversi Mazhab tentang Wakaf Uang dan Implikasinya terhadap Undang-Undang Nomor 41 Tahun 2004 tentang Wakaf.” Jurnal Ijtihad.Vol. 32. Nomor 2: 2016.

\section{Peraturan Perundangan-undangan}

Undang-Undang Nomor 41 Tahun 2004 tentang Wakaf.

Instruksi Presiden Nomor 1 Tahun 1991 tentang Kompilasi Hukum Islam. 